\title{
Developing the 3 Sentence Screening Test for Speech Sound Disorders and Prevalence in 6-Year-Old Children
}

\author{
Soo-Jin Kim \\ Department of Communication Disorders, Korea Nazarene University, Cheonan, Korea
}

Correspondence: Soo-Jin Kim, PhD

Department of Communication Disorders, Korea

Nazarene University, 48 Wolbong-ro, Seobuk-gu,

Cheonan 31172, Korea

Tel: $+82-41-570-7978$

Fax: +82-41-570-7846

E-mail: sjkim@kornu.ac.kr

Received: September 21, 2016

Revised: November 10, 2016

Accepted: November 15, 2016

This work was supported by the research fund of Korean Nazarene University.

\begin{abstract}
Objectives: There is no speech sound disorder (SSD) prevalence study in Korea. Adolescents with a history of SSD may experience a negative impact on their language and academic skills even though they no longer exhibit overt articulation errors, especially if their phonological errors have not been resolved by the age of 6 . This study aims to estimate the prevalence of SSD in 6-year-old Korean children, and to investigate the accuracy of the 3 Sentence Screening Test. Methods: To assess speech development, the 3 Sentence Screening Test was administered to 600 children around the age of 6 . The utterances were rated on a 4-point scale by clinicians, who then counted the number of errors in consonants/eojeols. Results: The accuracy of the screening test was best when cut-off score were more than two eojeol errors or more than three consonant errors. There was also a high correlation of 7 between the rating and the number of errors. The prevalence of SSD (rating 4, moderate to severe) in 6-year-old children was 2.3\%; and at-risk for SSD (rating 3, borderline to mild) was $5.8 \%$. Conclusion: The 3 Sentence Screening Test was shown to be a valid test tool for screening the speech development of 6-year-old children. This study provides a preliminary perspective on the prevalence of SSD in Korea.
\end{abstract}

Keywords: Speech sound disorders, Screening test, Prevalence, Articulation \& phonology disorders
의사소통장애 아동 중 말소리장애 아동의 비율에 대한 최근의 국내 조사연구(Kim, Kim, Ha, \& Ha, 2015)에서는 약 44\%는 말소 리장애가 있는 것으로 알려졌다. 의사소통장애 안에서 말소리장애 의 비중이 매우 큰 편이라고 할 수 있다. 말소리 산출 장애는 두드러 지게 눈에 띄는 문제이다. 학령전기뿐 아니라 학령기 이후에도 의 사소통, 학업, 사회적 관계 등에 영향을 미칠 수 있는 중요한 변수이 다. 최근의 대규모 종단연구에서 언어장애를 동반한 말소리장애 아동의 많은 경우가 학령기에 이르러 문해능력에 결함을 보이며 특 정학습 장애가 될 수 있는 것으로 밝혀지고 있다(Lewis et al., 2015). 언어장애동반 문제 이외에도 특히 6세를 전후로 한 초기 문해기술 을 습득하는 시점에 필요한 음운기술에 어려움을 보이면 문해기술 습득에도 어려움을 초래하게 된다. Bishop과 Adams (1990)는 종 단연구를 통해 5 세반까지 말소리문제를 보이는 아동의 경우 청소
년기에 이르기까지 말소리문제도 지속될 뿐 아니라 음운처리결함 등으로 읽기문제를 보이는 경우도 5 세반 이전에 말소리문제가 해 결된 집단에 비하여 높은 것을 확인해주었다. 학령전기에 말소리 산출에서 어려움을 보이던 아동들 중 많은 아동들이 학령기가 되 어서도 지속적인 말소리문제나 학습문제 이외에도 자아존중감이 나 사회적 관계 등 다양한 측면에 영향을 미칠 수 있는데, 이러한 후 기 영향을 잘 예측하는 시점을 5세반에서 6세반으로 보고 있다 (Bishop \& Adams, 1990; Lewis et al., 2015). 아동의 말소리문제에 대해 적절한 중재를 일찍 제공하는 것이 이후의 다른 문제들까지 최소화할 수 있다는 점에 대해서는 학자들 간에 이견이 없다. 조음 의 발달이 어느 정도 완성되어가면서, 학령기가 시작되는 학령전기 에 선별검사를 실시하여 필요한 도움을 제공할 수 있다면, 많은 말 소리장애 아동들이 학령기에 교우관계나 학업문제, 자아개념 등에 
손상을 줄 수 있는 2 차적인 문제들을 최소화 하거나 예방할 수 있 을 것이다.

출현율은 생애 일정한 시기에 질병이나 장애가 나타나는 경우를 의미한다. 따라서 말소리장애의 경우에는 연령대에 따라서 출현율 에 차이가 있다. 연령에 따른 연구결과들을 살펴보면 아동기 인구 의 5\%-10\% (Bernthal, Bankson, \& Flipsen, 2013), 학령기 인구의 약 $1.06 \%$ (McKinnon, McLeod, \& Reilly, 2007), 3세에서 11세 아동 의 약 7.5\% (Shriberg \& Kwiatkowski, 1994), 3세 아동의 약 $15.6 \%$ (Campbell et al., 2003), 6세 아동의 약 3.8\% (Shriberg, Tomblin, \& McSweeny, 1999) 등이 말소리를 보이는 비율로 보고되어 있다. 이 러한 말소리의 출현율은 모두 국외연구들로 아직 국내에서 수행된 말소리장애 출현율 연구는 전무한 실정이다.

국외연구를 살펴보아도 말소리장애는 진단명과 기준 등이 명확 하지 않아 출현율이 매우 다양하게 추정되고 있다. 오랜 기간 이루 어진 말소리장애 출현율 연구들을 비교 분석하여 많이 인용되고 있는 Law, Boyle, Harris, Harkness와 Nye (2000)의 문헌연구에 의 하면 5세에서 7세 사이 아동 중 $2 \%-25 \%$ 가 말소리장애를 보인다고 보고하였다. 말소리장애 인구의 조사 결과가 다양하게 나타난 원인 을 Kim 등(2015)은 두 가지로 파악하였는데, 그 하나는 유병률 조 사방법의 다양함이고 나머지 하나는 장애 자체의 정의 특성을 들 수 있다. 첫째로, 조사방법은 직접조사와 간접조사 등 다양한 방법 들이 사용되어 왔다. 간접조사의 경우 보고방식도 매우 다양한데 아동의 질병이나 장애 유무를 표시하도록 하거나, 필요한 지원의 정도를 평정하도록 하였다. 연령대에 따라 보고하는 사람에 따라 비중도 다르게 나타나는데 전문가와 교사 부모 세 집단의 보고를 비교해 보면 학령전기 아동은 부모의 보고가 전문가와 더 유사한 반면 학령기 아동의 경우는 교사의 보고가 전문가와 더 유사하였 다(McKinnon et al., 2007). 유창성장애나 조음장애 같은 말장애의 경우 주관적인 보고보다 선별평가 절차를 통하는 경우가 유병률이 높게 나타난다(Duff, Proctor, \& Yairi, 2004; Law et al., 2000). 두 번 째 원인으로 말소리장애의 정의가 연구마다 다르다는 점을 들었다. 말소리장애, 조음음운장애, 말장애, 음운장애, 조음장애, 기능적 조음음운장애 등 조사마다 다양한 진단명이 사용되었으며, 진단 명이 동일하다 하더라도 그 정의와 기준이 조사마다 달라서 목표대 상자가 동질적이지 못하다는 것이다. 뿐만 아니라 중증만을 포함 한 경우와 위험군까지 포함하는 경우도 전혀 다른 결과를 유도할 것이다. 보다 정확한 유병률을 구하고 싶다면 연구자들이 직접 선 별평가를 실시하여 말소리장애의 유병률을 구하는 것이 가장 이상 적이라고 제안하였다(Kim et al., 2015; Law et al., 2000).

말소리장애의 객관적이고 실증적인 기준을 수립하여 유병률을
구하고 최선의 정책을 수립하기 위해서는 직접 수행방식의 선별평 가 도구를 개발하는 것이 선행과제라고 할 수 있다. 그러나 국내의 말소리 선별평가 도구는 객관적인 표준화 검사로 개발된 바 없으며, 말소리장애를 어떻게 평가할 것인지에 대해서는 구체적인 고민이 논의된 바도 거의 없는 실정이다. 비공식적으로 사용되는 선별평가 도구들을 객관적이고 실증적인 표준화 검사 도구로 발전시킬 필요 가 있다. 비공식적으로 말소리장애 선별평가 도구로 사용되고 있는 5-6세용 '세 문장 선별검사'를 통하여 언어발달장애 아동의 선별평 가 도구로 활용될 수 있음을 보여주었다(Kim \& Han, 2015). 언어 발달 선별검사로 소개된 이 검사는 최초에 학령기 직전 아동의 말 소리장애를 선별하기 위하여 개발된 문장이었다(Kim \& Yu, 2014). '세 문장 선별검사'의 세 문장은 우리 말소리에서 상대적으로 어려 운 자음인 마찰음과 파찰음 및 유음을 다양한 어절내 위치와 음절 내 위치에서 살펴볼 수 있도록 하였으며, 특히 종성과 초성이 이어 서 산출되도록 하는 등 다양한 음소연결구성을 의도적으로 기획 한 문장이다. 임상에서 말소리문제를 평가하는 데 널리 사용되고 있는 문맥은 단어와 자발화지만 문장 따라말하기 과제를 통한 아 동의 말소리 평가는 여러 가지 측면에서 유용하다. 첫째로 일상생 활에서의 말소리 산출 능력을 관찰하기 위해서는 문장 수준의 과 제가 적절하다. 문장 수준의 말소리 산출 과제는 다양한 언어적 환 경, 즉 내용형태소와 문법형태소의 차이 등과 같은 요소들의 영향 력을 살펴볼 수도 있다(DuBois \& Bernthal, 1978; Johnson, Winney, \& Pederson, 1980; Kim, Kim, Yoon, Chang, \& Cha, 2012; Woo $\& \mathrm{Kim}, 2014)$. 둘째로 자발적인 산출이나 대화 과제에서는 선호하 는 소리를 위주로 산출하고 어려운 소리를 기피할 수 있는 반면, 똑 같이 모방하여 따라 말하도록 하여 짧은 시간 안에 목표하는 소리 를 다양한 조건에서 산출하게 할 수 있기 때문이다(Choi \& Kim, 2013; Kenney, Prather, Mooney, \& Jeruzal, 1984; Park \& Kim, 2015). 셋째로 문장 따라말하기 발화는 말소리장애뿐 아니라 언어장애의 선별에도 유용하다(Kim \& Han, 2015). 말소리장애를 갖고 있는 아 동 가운데 언어장애를 동반한 경우의 비중도 $60 \%$ 내외로 추정되 고 있다(Ko \& Kim, 2016). 따라서 선별평가 도구로뿐 아니라 말소 리장애의 진단평가를 수행할 때 말과 언어를 함께 볼 수 있는 검사 로 진행할 만하다.

'세 문장 선별검사'의 공인타당도를 알아보기 위하여 기존에 사 용되는 말소리장애 검사결과와상관을 구한 결과 오류점수는 $\mathrm{APAC}$ 검사와 -.89, UTAP 검사와 -.88의 높은 상관을 보였다(Kim, 2016). 그러나 이 검사는 예비연구 수준에서만 검토되었을 뿐 현장에서 사용되기 위해서는 보다 대규모 표집을 통하여 선별정확도를 확인 하고 표준화시켜 절사치 점수를 제공할 필요가 있다. 말소리문제의 
평가를 위한 채점 방식도 여러 가지가 있는데, 그 평가 방식에 대한 타당성도 확인할 필요가 있다. 임상에서도 일상적으로 말소리문제 를 채점하는 방식으로는 평정법과 직접 채점방법이 동시에 활용되 고 있다(Kim \& Shin, 2015). 아동의 말소리 채점 방식으로 가장 널 리 사용되는 것으로는 자음정확도(percentage of correct consonants, PCC)가 있으나 이는 어느 정도 훈련이 필요한 채점 방식이 다. 자음정확도와 함께 사용할 수 있으면서 문장과제에서 더 간편 한 지표로 단어단위 정확률(percentage of whole-word correctness, $\mathrm{PWC})$ 이 있다. 단어단위 정확률은 발화에서 정확하게 발음된 단어 혹은 어절 수를 세는 방식으로 매우 간편한 직접 수행 채점 방식이 라고 할 수 있다. 비전문가들이 실시하는 경우를 고려한다면 정확 하게 발음한 것을 모두 세도록 하는 정확률 방식보다는, 오류가 있 거나 이상하게 들린 부분을 표시하여 세도록 하는 채점 방식이 보 다 편리하고 효율적이므로 이 지표들은 오류자음 수(incorrect consonants) 혹은 오류단어 수(whole-word incorrectness) 등으로 응 용하여 활용될 수 있을 것이다. 또한 임상현장에서도 널리 사용되 는 평정법이 있다. 훈련받은 언어치료사라면 아동이 따라 산출한 세 개의 문장과제를 듣고 정상적인 발달수준인지, 심화검사를 받 아볼 것인지 혹은 말소리장애가 심각한 수준인지 등을 평정법으로 간단하게 평가할 수 있다. 평정치는 말소리장애 아동을 선별하거나 명료도와 심각도를 결정하는 데에 짧은 시간 안에 수행할 수 있어 임상에서 매우 효율적이며 타당한 방법으로 활용되고 있다(Gordon-Brannan \& Hodson, 2000; Munson, Johnson, \& Edwards, 2012; Rafaat, Rvachew, \& Russell, 1995).

연구문제는 다음과 같다. 첫째, 6세 아동의 말소리 발달 선별을 위해 개발한 '세 문장 선별검사'의 오류자음과 오류어절 수에 대하 여 ROC곡선을 통한 절사치가 말소리장애 평정 점수를 예측하는 정도와 선별정확도를 구하고자 한다. 둘째로 선별검사 과제의 세 가지 채점 결과 즉 평정치와 오류자음 수, 오류어절 수의 관계를 분 석하고자 한다. 마지막으로 일반유치원과 어린이집에 다니는 6세 (5;6-6;5) 아동 가운데 말소리장애 위험군 아동의 출현율을 알아보 고자 한다.

\section{연구 방법}

\section{대상자}

서울경기권에서 남녀 400 명, 충청권에서 남녀 200 명 총 600 명의 아동에게 선별검사를 실시하였다. 두 지역 모두 남아와 여아의 비 율은 동일하게 각각 300 명이다. 유치원 혹은 어린이집을 다니고 있 는 5;6세부터 6;5세까지의 아동을 대상으로 하였다. 연령기준 범위
에만 해당되는 경우, 다른 장애나 행동상 특징이나 다문화 배경 등 을 이유로 배제하지 않고, 부모가 검사에 동의를 한 모든 아동에게 실시하였다. 컴퓨터를 이용한 놀이동산 선별검사의 연습문장 “오 늘은 일요일입니다" 라는 문장을 따라 말하도록 지시하고 3회 이 상 연습해도 문장을 따라 말하지 못하고 낱말로 말하거나 반응을 하지 않는 경우 선별검사를 실시하지 않았다. 600 명을 녹음하는 과 정에서 17 명이 연습문장만 시도하고 본 검사에 참여하지 않았거 나, 녹음이상으로 분석에서 제외되었다. 아동의 연령 평균은 6 세 0 개월 $(\mathrm{SD}=4.1$ 개월 $)$ 이었다.

\section{도구}

놀이동산 선별검사 도구는 세 문장으로 구성되어 있으며, 반응 기록지, 말소리문제 채점 기준 및 컴퓨터 화면은 Appendix 1에 제 시하였다. 세 문장은 18 어절, 64 자음을 포함하고 있다. 문장발화의 경우 조음 측면에서 볼 때 한국어의 경우 단어보다는 어절을 세는 것이 편리한 점을 고려하여 자음과 어절을 단위로 채점기록지를 구 성하였다.

자극단서를 일정하게 유지하고 녹음과 파일 저장 등을 자동으 로 수행할 수 있도록 하기 위하여 컴퓨터 프로그램으로 검사를 제 작하였으며, 한 문장씩 검사문장을 들려주고, 녹음버튼을 누르면 화면의 색이 바뀌면서 아동이 따라 말하고 녹음이 되도록 하였다.

\section{절차}

검사를 진행하는 사람들에게는 프로그램이 담긴 노트북을 배포 하고, 세 시간 동안 선별검사 실시방법에 대한 설명과 실습 워크샵 을 실시하였다. 말소리장애 출현율 연구의 의의를 설명하고 장애가 있거나 없는 아동 모두가 참여할 수 있도록 유치원교사와 부모에게 협조를 구하였다. 유치원 혹은 어린이집에서 제공한 개별 평가 공 간에서 아동에 대한 검사를 직접 개별적으로 실시하였다. 선별검 사 진행은 우선 아동에게 검사방법을 충분히 설명하고, 연습문항 (“오늘은 일요일입니다”)을 실시하고 실패한 경우 3 회까지 설명과 연습을 반복하여 수행에 성공한 아동에게 본 검사를 실시하였다. 컴퓨터로 아동 발화를 녹음한 후 발음전사하고 채점하였다. 선별 검사소요시간은 연습문항을 포함하여 3 분 정도이다.

평가는 평정과 오류빈도 세기 두 가지 방식으로 수행하였다. 첫 번째 평정은 말소리장애 위험도에 대한 4 점 척도로, 평정자는 1년 이상의 언어치료사 경력이 있는 언어치료전공 대학원생들(평정자) 이 실시하였다. 두 번째로 오류빈도 세기는 언어치료전공 학부생 (채점자)이 Appendix 1에 제시한 채점지에 우선 아동이 오류를 보 인 어절의 발음을 그대로 전사한 뒤, 오류가 나타난 자음 수와 어절 
수를 세어서 기록하도록 하였다. 검사자와 채점자 평정자는 모두 다른 사람들이 수행하여 각각 절차의 독립성을 유지하였다. 평정척 도는 4 점 체계로 평정자에게 다음과 같은 점수의 의미를 설명하였 다. 1점은 말소리 오류 없음, 2점은 말소리 오류 있지만 말소리문제 없음, 3점은 말소리장애 심화검사가 필요함(경계선급-경도), 4점은 말소리장애 있으며 중재가 필요함(중등도-중도)을 의미한다.

아동 발화의 전사 및 오류어절과 오류자음 수 채점은 채점자 한 명당 60 명씩의 아동을 채점하도록 하였다. 채점 워크샵을 진행한 뒤 연습용 자료 10 명의 30 개 문장을 듣고 전사하여 오류자음 수와 오류어절 수를 채점하도록 하고, 다시 모여서 불일치 하는 경우에 대하여 함께 토론하고 연습한 후 $100 \%$ 일치할 때까지 연습을 반복 하였다. 연습이 끝난 후에 본 자료 60 명씩을 전사하고 채점하였다. 필요하다면 컴퓨터로 무한 반복하여 듣거나, 2 배속으로 느리게 듣 거나, 헤드폰을 사용하여 듣도록 하였다. 오류 수를 셀 때는 언어적 오류는 배제하고, 조음오류로 대치와 생략 첨가만 포함되며, 선별 검사임을 고려하여 왜곡오류는 포함하지 않았다.

말소리장애 평정은 언어치료 경험이 있는 전공 대학원생 평정자 6 명이 아동 100 명씩을 평정하도록 하였다. 평정자들도 위의 채점자 들과 같이 10 명의 연습용 자료를 통해 평정치를 $100 \%$ 일치할 수 있 도록 연습을 하였고, 연습이 끝난 후에 평가하였다. 평정치 채점은 평정치는 다음과 같은 4점 척도에 체크(V)로 표시하도록 하였다. 3 점 혹은 4점을 받은 경우에는 부모에게 개별적으로 말. 언어 발달검 사를 받아볼 것을 추천하였다. 평정치에서 3 점과 4 점을 받은 아동 을 말소리장애 위험군으로 분류하여, ROC곡선에서 오류자음과 어절수의 변별도를 분석 제시하였다.

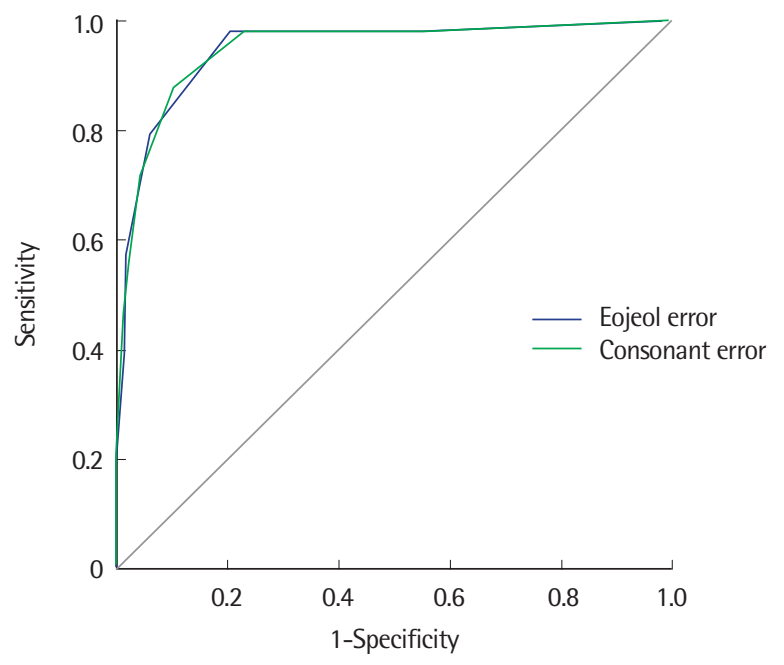

Figure 1. Receiver operating characteristic (ROC) curve.
평정자 6 명 각각의 자료 중 10 명씩 무선적으로 선정하여 총 60 명 아동에 대하여 말소리장애 전공 연구자 1 인이 평정하여 평정자와 의 일치도를 구하였다. 전체 자료의 $10 \%$ 에 해당하는 60 명 아동자 료에 평정치 일치도는 $91.7 \%$ 였다. 평정치에서 불일치한 아동 5 명은 1점과 2점 사이에서 2명, 3점과 4점 사이에서 3명이 있었는데 2점 이상 차이가 나는 경우는 없었으며, 일반군과 말소리장애 위험군 을 나누는 2점과 3 점 사이에 불일치는 없었다.

\section{연구 결과}

\section{세 문장 선별검사의 선별정확도}

말소리 선별검사의 평정치로 나눈 일반집단(평정치 1점과 2점)과 말소리장애 위험집단(평정치 3점과 4점)을 오류자음 수와 오류어 절 수가 변별한 정도를 알아보기 위해 구한 ROC곡선은 Figure 1과 같다.

$\mathrm{ROC}$ 곡선 분석을 통한 절사치, 민감도, 특이도 및 진단정확도를 Table 1에 제시하였다. 말소리장애 위험수준(3점 이상)을 받은 집단 과 말소리장애가 없다고 판단된(2점 이하) 두 집단별 오류자음 수 와 오류어절 수의 ROC면적률은 각각 .947 ( $p<.001)$ 로 매우 높게 나타났으며, 절사치는 민감도와 특이도의 합이 제일 높은 점수로 오류어절 수 1.5 개, 오류자음 수는 2.5 개였다. 이렇게 두 집단을 구 분하였을 때 민감도와 특이도, 타당도는 Table 1과 같다.

\section{말소리장애 평정치와 오류자음 및 오류어절 수의 관계}

말소리장애 평정치에 따른 오류자음과 오류어절의 평균 및 표준 편차 범위는 Table 2 와 같다. 6 세 아동 600 명 전체의 평균 오류자음 수는 1.33 개로 평균 자음정확도 $97.9 \%$ 로 나타났다. 말소리문제가 없다고 판단된 평정치 1 점을 받은 아동의 평균 자음오류는 0.32 개 였으며, 오류는 있지만 말소리문제는 없다고 판단된 2점을 받은 아 동의 평균 자음오류는 1.62 개였다. 말소리산출에 문제가 있는 것으 로 의심되며 보다 정밀한 검사를 수행할 필요가 있다고 평정된 3점 을 받은 아동의 평균 자음오류는 4.2 개였다. 확실하게 말소리산출

Table 1. Accuracy of the speech sound disorder screening test in 6-year-old children

\begin{tabular}{lccccc}
\hline Scale & AUC & $\begin{array}{c}\text { Cut-off } \\
\text { value }\end{array}$ & $\begin{array}{c}\text { Sensitivity } \\
(\%)\end{array}$ & $\begin{array}{c}\text { Specificity } \\
(\%)\end{array}$ & $\begin{array}{c}\text { Validity } \\
(\%)\end{array}$ \\
\hline Eojeol error & $.947^{* *}$ & 1.5 & 79.6 & 93.8 & 92.7 \\
Consonant error & $.947^{* *}$ & 2.5 & 71.4 & 95.6 & 93.7 \\
\hline
\end{tabular}

$\mathrm{AUC}=$ area under curve.

${ }^{* *} p<.001$. 
문제를 갖고 있음을 의미하는 4점을 받은 아동의 평균 오류자음의 개수는 9.29개였다. 다른 평정 점수를 받은 아동들에 비해 가장 적 은 14 명임에도 불구하고 자음오류의 표준편차가 5 개 이상이며 오 류의 범위도 5 개부터 21 개까지 매우 광범위하였다. 임상현장에서 가장 널리 사용되는 자음정확도(PCC)로 바꿔서 보면 전체 평균은 $97.9 \%$ 이고 1점을 받은 아동의 평균은 $99.5 \%$ 였으며 4점을 받은 아 동의 평균은 $85.5 \%$ 였다.

전체 아동의 오류어절 평균은 1.11 개였다. 전혀 문제가 없다는 1 점을 받은 아동의 오류어절 평균은 .30 이었으며, 2 점은 평균 $1.42,3$ 점은 평균 3.46 개의 오류를 보였다. 말소리장애가 확실하다는 4점 을 받은 아동의 오류어절은 평균 6.07 개였다. 오류어절에 있어서도 4점을 받은 아동은 14 명임에도 불구하고 표준편차가 약 2.95 로 가

Table 2. Descriptive data by rating score

\begin{tabular}{llccccc}
\hline & \multicolumn{5}{c}{ Rating $^{\mathrm{a}}$} & \multirow{2}{*}{ Total } \\
\cline { 3 - 6 } & & \multicolumn{1}{c}{2} & \multicolumn{1}{c}{3} & 4 & \\
\hline Number of subjects (\%) & $284(48)$ & $267(44)$ & $35(6)$ & $14(2)$ & $600(100)$ \\
PCC & Mean & 99.5 & 97.5 & 93.4 & 85.5 & 97.9 \\
Error conso- & Mean & .32 & 1.62 & 4.20 & 9.29 & 1.33 \\
nants & SD & .66 & 1.29 & 1.94 & 5.20 & 2.06 \\
& Range & 3 & 7 & 9 & 16 & 21 \\
\multirow{2}{*}{ Error eojeols } & Mean & .30 & 1.42 & 3.46 & 6.07 & 1.11 \\
& SD & .60 & 1.00 & 1.48 & 2.95 & 1.48 \\
& Range & 3 & 5 & 7 & 9 & 12 \\
\hline
\end{tabular}

$\mathrm{PCC}=$ percentage of correct consonants; $\mathrm{SSD}=$ speech sound disorder. aRating score: 1 = no SSD; 2 = sound errors but no SSD; 3 = at risk for SSD; $4=$ SSD.
장 크고, 오류어절의 범위도 4 개부터 12 개까지 광범위하게 나타났 다. 평정점수에 따른 오류자음 수(errorC)와 오류어절 수(errorE)의 분포는 Figure 2와 같다.

말소리장애 평정 결과와 오류자음 수 오류어절 수의 상관은 $\mathrm{Ta}-$ ble 3 과 같다. 오류자음 수와 오류어절 수는 .98로 매우 높은 상관 을 보였으며, 평정치와 오류자음 및 오류어절 수는 .7 이상의 상관 을 나타냈다.

\section{6세 아동의 말소리장애 선별 아동의 비율}

확실하게 말소리장애로 평정한 아동은 14 명(2.3\%)이었으며, 말 소리장애 위험이 있음을 의미하는 3점을 받은 아동은 35 명 $(5.8 \%)$ 이다. 즉, 말소리장애가 있는 것으로 의심되는 3점과 확실하게 말소 리장애가 있다는 4점을 받아서 말소리장애 위험이 있다는 평정을 받은 아동은 검사대상 600 명 전체에서 약 $8 \%$ (49명)로 나타났으며, 말소리장애가 없음을 의미하는 1점과 2점을 받은 아동은 $92 \%$ (551 명)로 나타났다(Table 2, Figure 3).

Table 3. Correlations among the scores on the speech sound screening test (Spearman's rho)

\begin{tabular}{lcc}
\hline & Consonant error & Eojeol error \\
\hline Rating & $.709^{* *}$ & $.712^{* *}$ \\
Consonant error & - & $.981^{* *}$ \\
\hline
\end{tabular}

${ }^{* *} p<.01$.

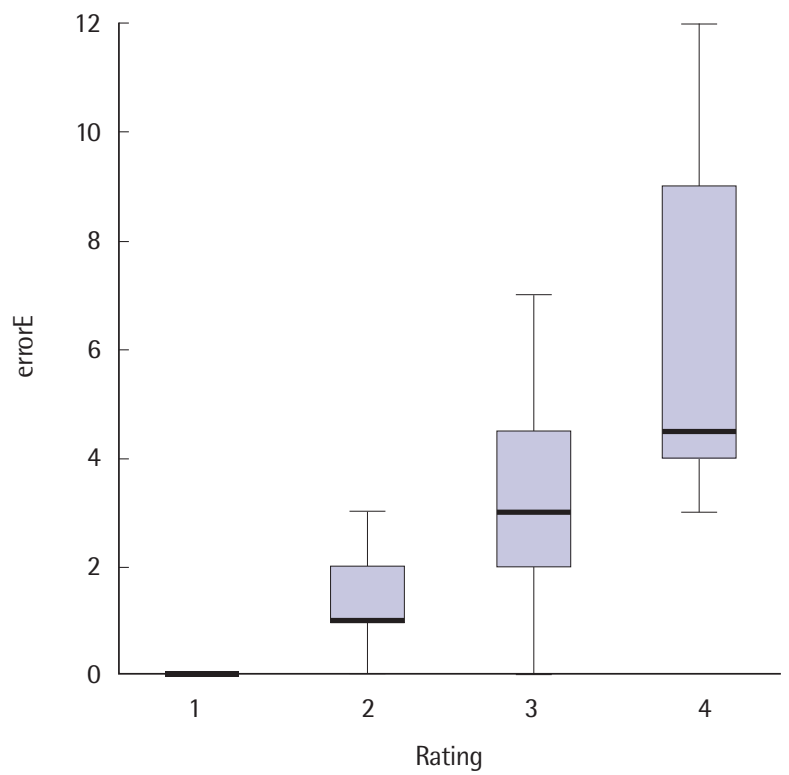

Figure 2. Box graph of error consonants (errorC) \& error eojeols (errorE) by rating score. 


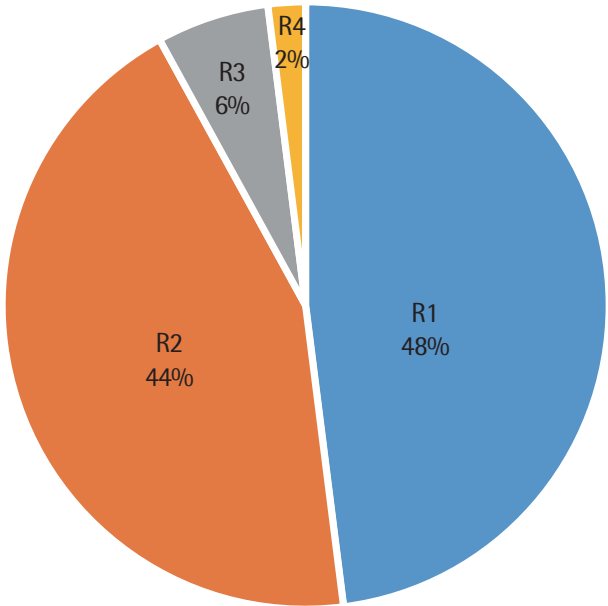

Figure 3. Percentage of participants by rating score $(R 1 \& R 2=$ no speech sound disorder; $\mathrm{R} 3=$ borderline to mild; $\mathrm{R} 4=$ moderate to severe).

\section{논의 및 결론}

본 연구의 첫 번째 목적은 개발된 선별검사의 선별정확도를 확인 하는 것이었다. 선별검사를 실시하여 구한 오류자음 수와 오류어 절 수가 치료사의 평정 점수를 얼마나 예측하는지 확인하기 위하 여 ROC곡선과 최적의 절사치를 구하여 민감도와 특이도 타당도를 구하였다. ROC곡선 아래 면적이 변별 예측력을 의미하는데 .7-.8 내외이면 변별도가 있다고 할 수 있는데 오류어절과 오류자음 수 모두 .978로 변별도가 매우 높은 것으로 나타났다. 문장 따라말하 기 선별검사는 컴퓨터를 활용한 검사(Appendix 1)로 일반인이 수 행하였으며 녹음된 발화를 듣고 전공자가 채점하였다. 약간의 연 습만 한다면 일반 교사들도 발음을 전사하고 절사치를 기준으로 심화검사를 의뢰할 수 있도록 할 수 있다. 5 세 후반에서 6 세 전반의 아동에게 선별검사를 실시하고 세 개 이상의 오류가 나타난 경우 에 심화검사를 의뢰할 수 있을 것이다. 컴퓨터 프로그램이 없는 경 우에도 부록에 제공한 채점지를 기준으로 직접 들려주고 따라하도 록 수행한 결과가 컴퓨터를 이용한 수행결과와 유사한 것으로 나 타났다(Oh \& Kim, 2016). 그러나 대상 연령이 5세 후반에서 6세 전 반으로 국한되어 있으므로 말소리장애의 선별이 필요한 더 어린 아 동을 대상으로 한 적용 가능성을 확인하기 위해서는 추가적인 다 른 연구가 필요하다.

두 번째 목적은 따라말한 세 문장의 세 가지 다른 채점방식 즉오 류자음과 오류어절 수 및 말소리장애 평정치의 관계를 분석하는 것이다. 직접 오류를 세는 방식의 오류자음과 오류어절은 .98 의 상 관을 보였으며, 평정치는 오류자음과 오류어절 각각 .71로 중간 이
상의 상관을 나타냈다. 그러나 Figure 2에서 보이는 바와 같이 평정 점수에 따라 구분된 집단별 오류자음 수와 오류어절 수의 범위는 거의 정확하게 나뉘어 분포되어 있다. 평정치에서 말소리오류가 없 음을 의미하는 1 점을 받은 아동의 비율은 $48 \%$ 로 평균 0.3 개의 자 음과 어절에서 오류를 보였다. 말소리오류는 있지만 말소리장애는 아니라는 2 점을 받은 아동의 비율은 $44 \%$ 로 평균 1.6 개의 자음, 1.4 개의 어절에서 오류를 보였다. 말소리장애 위험군이며 심화검사를 받도록 추천한 3 점을 받은 아동은 $5.8 \%$ 로 평균 4.2 개의 자음, 3.5 개 의 어절에서 오류를 보였다. 마지막으로 분명한 말소리장애라는 진 단을 내릴 수 있음을 의미하는 4점을 받은 아동은 $2.3 \%$ 로 평균 9.3 개의 자음, 6 개의 어절에서 오류를 보였다. 전문가들이 선별검사를 채점하는 경우 말소리장애 진단 경험을 바탕으로 평정점수를 부과 할 수 있으며 이 평정점수는 심화검사를 추천하거나 언어치료를 받 도록 의뢰하는데 직접적인 의견으로 활용될 수 있을 것이다.

본 연구의 마지막 목적은 개발된 선별검사를 통해 6세 아동의 말 소리장애 위험군의 비율을 알아보기 위한 것이었다. 언어치료사가 직접 선별검사의 세 문장 발화를 듣고 말소리장애 위험여부를 평정 하도록 한 결과, 말소리장애가 확실하게 있거나 위험이 있다고 평정 된 아동은 49 명(8\%)이고 말소리장애가 없다고 평가된 아동은 551 명(92\%)이었다. 이 중 14명(2.3\%)은 확실하지만 35명(5.8\%)은 말소 리장애의 위험이 있으며 추후 심화검사가 필요하다고 분류 평가하 였다. 본 연구의 대상은 만6세 전후 아동으로 유사한 연령대를 직 접 평가한 이전 국외 출현율 연구결과들을 살펴보면, Shriberg 등 (1999)은 6세 아동의 약 $3.8 \%$, Kirkpatrick과 Ward (1984)는 5세부 터 7세 아동의 4.6\%, Harasty와 Reid (1994)는 6세부터 12세 아동 의 $12.6 \%$ 라고 보고하였다. 경계선급이나 경도 말소리장애를 포함 할 것인지에 따라 말소리장애의 출현율을 다양하게 제시할 수 있 는데, 이 연구의 결과에서도 제한적이지만 경계선급 의심군을 포함 할 것인지에 따라 $2 \%-8 \%$ (중재가 필요한 확실한 말소리장애를 의 미하는 평정치 4 점은 $2.3 \%$, 심화검사가 필요하며 말소리장애 위험 군을 포함하는 평정치 3-4점은 8.1\%)라고 할 수 있다. 여기에서 제 한적이라고 하는 이유는 표집된 600 명의 아동이 통합교육을 하고 있기는 하지만 모두 일반 보육, 교육시설을 다니는 아동이기 때문 이다. 소수이기는 하지만 장애아 전담 어린이집이나 특수교육기관 의 유치원, 가정보육 아동을 포함한 출현율을 추정하는 것은 어렵 다. 또한 추가적으로 심화검사가 필요한 위험군으로 선별된 아동들 에게 표준화 검사를 포함한 심화평가 절차를 통해 정확하게 말소 리장애로 진단된 아동의 수를 파악해야 하며, 검사 진행 당시 연습 문항을 수행하지 못해서 제외된 17 명의 아동에 대해서도 고려할 필요가 있다. 문장 따라말하기 연습문항을 실패한 경우는 심한 지 
적장애, 언어장애 아동 등이 포함되어 있는데, 이 연구에서는 경도 장애 아동은 포함되어 있지만 중도장애 아동들이 배제되어 있으 며, 서울과 충청지역에 국한되어 있으므로 전국적인 차원의 정확한 출현율로 보기에는 한계가 있음을 의미한다.

언어치료 임상현장에서는 중도 이상의 지적장애와 언어장애 아 동이 말소리산출에 문제가 있는 경우 말소리장애 아동으로 분류할 것인지에 대해서 합의되어 있지 않다. 출현율에 대한 본격적인 논 의를 위해서는 말소리장애의 정의와 분류 원칙에 대한 점검이 필요 하다. 국외의 경우에도 연구마다 기준에 차이가 있지만, 일반적으 로는 지적장애와 언어장애 아동의 말소리문제도 말소리장애로 진 단을 내린다. 6 세 아동 1,500 명에 대한 대규모 자료분석에서 말소리 장애 출현율을 $3.8 \%$ 라고 보고한 Shriberg 등(1999)은 50여 년간 세 계 각 지역에서 100 여 개 이상의 말소리장애 출현율 연구를 검토한 결과 일관된 수준의 결과를 얻지 못한 가장 큰 이유를 동반장애 문 제를 어떻게 개념화할 것인지에 따른 것으로 보았다. 이 문제를 보 완하기 위하여 일반아동, 언어장애 아동, 지적장애 아동 안에서의 말소리장애 출현율을 추가로 분석하였다. 일반아동에서는 $2.5 \%$, 언어장애 아동(SLI)에서는 $6.5 \%$, 지적장애만 있는 경우에서는 $4.5 \%$, 지적장애와 언어장애가 함께 있는 경우는 $16 \%$ 로 나타나서 언어장 애나 지적장애가 있는 경우에 일반아동에서보다 말소리장애 출현 율이 높게 나타난다고 보고하였다. 또한 일반아동의 경우에는 남 아가 $3.8 \%$, 여아가 $1.5 \%$ 로 나타났고 언어장애가 있는 경우에도 남 아가 더 높게 나타났지만 지적장애가 동반된 경우에는 여아의 출현 율이 더 높게 나타났다. 이러한 인구학적 영향요소와 동반문제에 따른 출현율 연구결과는 말소리장애의 체계적인 분류 틀을 마련하 는데 활용될 수 있을 것이다.

이 연구의 의의는 학령기 직전인 6 세 아동의 말소리문제 선별검 사를 개발하여 선별정확도를 평가한 점과, 개발된 선별검사로 말소 리장애 출현율을 직접 평가하여 구한 최초의 연구라는 점에 있다. 정확한 조사를 위해서는 부모나 전문가를 통한 조사 방식 보다는 직접적인 수행 평가를 통해야 하지만 비용과 시간이 많이 필요하 여 제한적일 수 밖에 없다. 그러나 장애인구의 현황을 파악하는 것 은 진단과 치료 접근에 대한 방향성 및 추후 장애에 대한 의료적 처 치와 교육, 치료적 지원 등 정부차원의 공공정책 방향 설정에 기초 가 되기 때문에 매우 중요하다. 출현율 연구는 가장 기초적인 역학 조사로, 우선 출현율이 파악되어야 해당 문제에 대한 지원 서비스 를 계획할 수 있다(Kim et al., 2015; McKinnon et al., 2007). 더 나 아가 관련 전문가들의 양성 및 교육 정책을 세울 수 있다. 현실적으 로 객관적인 요구조사에 기반하여 교육과정을 개발하고, 한정된 자원을 어떻게 배분해야 할지 결정하기 위해서는 장애종류에 따른
다양한 출현율 연구가 지속적으로 나와야 할 필요가 있다.

본 연구는 우선 선별검사 도구의 유용성을 평가하고, 특정 지역 과 연령대에서의 출현율만 조사하였다. 앞으로의 연구에서는 지역 별, 연령별, 성별, 부모의 사회경제적 지위 등 다양한 인구학적 변수 에 따른 출현율뿐 아니라 말소리장애와 관련된 동반문제들도 조사 해야 할 것이며 특히 종단적 추적연구가 필요하다. 조음음운장애 가 있던 아동들이 성인이 되었을 때를 추적한 결과 약 $50 \%$ 의 경우 문장수준에서 발음에 오류를 보였으며, 아동기에 언어문제는 없고 말소리문제만 있던 아동들이 말소리문제도 없던 비교집단에 비해 성인기에 언어문제를 보이는 확률이 높은 것으로 나타났다 (Felsenfeld, Broen, \& McGue, 1992). 언어문제를 동반했던 6세 말 소리장애 아동의 경우 학령기와 청소년기에 언어뿐 아니라 읽기 쓰 기에도 어려움을 보이는 것으로 나타났으며(Lewis et al., 2015), 대 규모 조사연구에서 아동의 말소리장애는 부모의 사회경제적 지위 와 관련성이 낮았지만 아동의 전반적인 다른 건강문제와상관이 높 게 나타나고 있음을 보여주었다(Keating, Turrell, \& Ozanne, 2001). 이는 말소리 발달에 문제가 있는 아동은 이후에도 말과 언어발달 뿐 아니라 다른 건강과 관련된 요소에서 취약할 수 있음을 반영하 는 것이다. 향후 국내에서도 보다 다양한 요인에 따른 말소리장애 출현율 연구와 더불어 이 결과를 반영하는 정교한 지원전략을 수 립해야할 것이다.

\section{REFERENCES}

Bernthal, J. E., Bankson, N. W., \& Flipsen, P. (2013). Articulation and phonological disorders: speech sound disorders in children (7th ed.). Boston, MA; Pearson.

Bishop, D. V., \& Adams, C. (1990). A prospective study of the relationship between specific language impairment, phonological disorders and reading retardation. Journal of Child Psychology and Psychiatry, 31, 1027-1050.

Campbell, T. F., Dollaghan, C. A., Rockette, H. E., Paradise, J. L., Feldman, H. M., Shriberg, L. D., ... \& Kurs-Lasky, M. (2003). Risk factors for speech delay of unknown origin in 3-year-old children. Child Development, 74, 346357.

Choi, M. S., \& Kim, S. J. (2013). Morphological influences on liquid acquisition in Korean children's spontaneous speech. Communication Sciences \& Disorders, 18, 76-85.

DuBois, E. M., \& Bernthal, J. E. (1978). A comparison of three methods for obtaining articulatory responses. Journal of Speech and Hearing Disorders, 43, 295-305. 
Duff, M. C., Proctor, A., \& Yairi, E. (2004). Prevalence of voice disorders in African American and European American preschoolers. Journal of Voice, $18,348-353$.

Felsenfeld, S., Broen, P. A., \& McGue, M. (1992). A 28-year follow-up of adults with a history of moderate phonological disorder: linguistic and personality results. Journal of Speech, Language, and Hearing Research, 35, 11141125.

Gordon-Brannan, M., \& Hodson, B. W. (2000). Intelligibility/severity measurements of prekindergarten children's speech. American Journal of SpeechLanguage Pathology, 9, 141-150.

Johnson, J. P., Winney, B. L., \& Pederson, O. T. (1980). Single word versus connected speech articulation testing. Language, Speech, and Hearing Services in Schools, 11, 175-179.

Keating, D., Turrell, G., \& Ozanne, A. (2001). Childhood speech disorders: reported prevalence, comorbidity and socioeconomic profile. Journal of Paediatrics and Child Health, 37, 431-436.

Kenney, K. W., Prather, E. M., Mooney, M. A., \& Jeruzal, N. C. (1984). Comparisons among three articulation sampling procedures with preschool children. Journal of Speech, Language, and Hearing Research, 27, 226-231.

Kim, S. J. (2016). The development of speech sound disorders screening test for 5- to 6-year-old children. Proceedings of the 2016 Conference of Korean Academy of Speech-Language Pathology and Audiology, 212-213.

Kim, S. J., \& Han, Y. J. (2015). The validity and accuracy of amusement park screening test in 5- to 6-year-old children using a computer. Journal of SpeechLanguage \& Hearing Disorders, 24, 391-400.

Kim, S. J., \& Shin, J. Y. (2015). Speech sound disorders. Seoul: Sigma Press.

Kim, S. J., \& Yu, H. J. (2014). Developing the speech screening test for preschool children. Proceedings of the 2014 Annual Conference of the Korean Academy of Speech-Language Pathology and Audiology, 43-46.

Kim, S. J., Kim, J. M., Yoon, M. S., Chang, M. S., \& Cha, J. E. (2012). Alveolar fricative sound errors by the type of morpheme in the spontaneous speech of 3- and 4-year-old children. Journal of the Korean Society of Speech Sciences, 4, 129-136.

Kim, S. J., Kim, M. J., Ha, S., \& Ha, J. W. (2015). A survey of speech sound disorders in clinical settings. Communication Sciences \& Disorders, 20, 133 144.

Ko, Y. K., \& Kim, S. J. (2016). Language characteristics of children with speech sound disorders of unknown origin. Proceedings of the 2016 Spring Conference of Korean Society of Speech Sciences, 149-150.

Law, J., Boyle, J., Harris, F., Harkness, A., \& Nye, C. (2000). Prevalence and natural history of primary speech and language delay: findings from a systematic review of the literature. International Journal of Language \& Communication Disorders, 35, 165-188.

Lewis, B. A., Freebairn, L., Tag, J., Ciesla, A. A., Iyengar, S. K., Stein, C. M., \& Taylor, H. G. (2015). Adolescent outcomes of children with early speech sound disorders with and without language impairment. American Journal of Speech-Language Pathology, 24, 150-163.

McKinnon, D. H., McLeod, S., \& Reilly, S. (2007). The prevalence of stuttering, voice, and speech-sound disorders in primary school students in Australia. Language, Speech, and Hearing Services in Schools, 38, 5-15.

Munson, B., Johnson, J. M., \& Edwards, J. (2012). The role of experience in the perception of phonetic detail in children's speech: a comparison between speech-language pathologists and clinically untrained listeners. American Journal of Speech-Language Pathology, 21, 124-139.

Oh, G. A., \& Kim, S. J. (2016). A comparison between computer-based and paper-based sentence repetition tests conducted on 5 and 6-year-old children. Proceedings of the 2016 Spring Conference of Korean Society of Speech Sciences, 143-144.

Park, K., \& Kim, S. J. (2015). A comparison of phonological error patterns in the single word and spontaneous speech of children with speech sound disorders. Phonetics and Speech Sciences, 7, 165-173.

Rafaat, S. K., Rvachew, S., \& Russell, R. S. (1995). Reliability of clinician judgments of severity of phonological impairment. American Journal of SpeechLanguage Pathology, 4, 39-46.

Shriberg, L. D., \& Kwiatkowski, J. (1994). Developmental phonological disorders I: a clinical profile. Journal of Speech, Language, and Hearing Research, $37,1100-1126$

Shriberg, L. D., Tomblin, J. B., \& McSweeny, J. L. (1999). Prevalence of speech delay in 6-year-old children and comorbidity with language impairment. Journal of Speech, Language, and Hearing Research, 42, 1461-1481.

Woo, H., \& Kim, S. J. (2013). Coda sounds acquisition at word medial position in three and four year old children's spontaneous speech. Phonetics and Speech Sciences, 5, 73-81. 
Appendix 1. A 3-Sentence-Screening-Test by computer for Korean speech sound disorders (scoring example)

이름(ID): ) 생년월일: ( ; ) 성별: 검사일: 검사자:

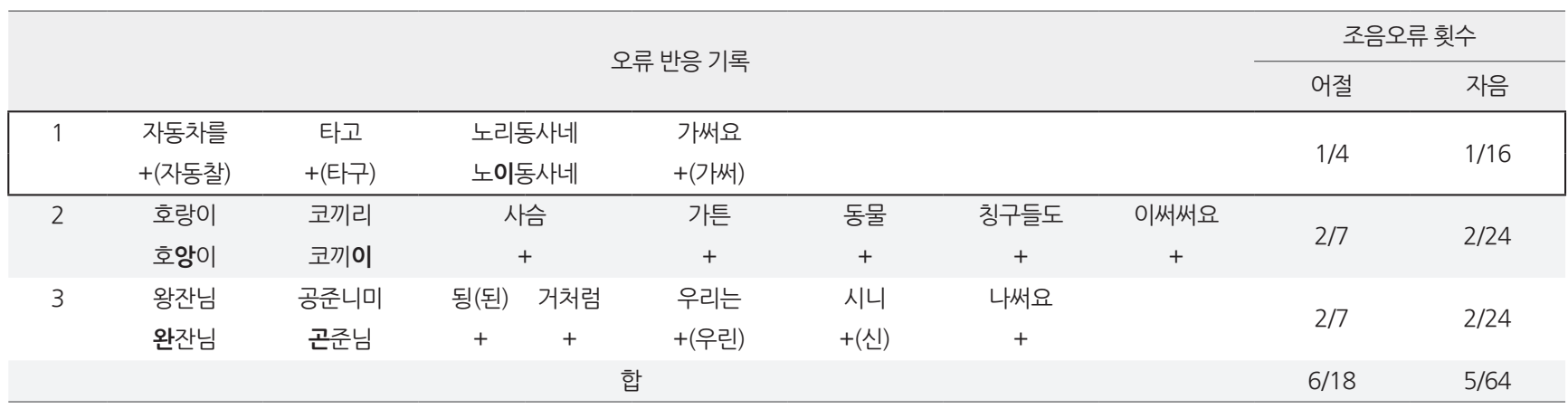

\section{채점 방법}

1. 아동의 반응 중 발음에 오류가 있는 경우에는 오류발음 그대로 적고, 정확한 발음은 '十’로 기록한다.

2. 스스로 교정해서 말할 때 교정한 것이 맞으면 맞는 것으로, 틀리면 틀린 것으로 채점한다.

3. 아동이 지시문과 다르게 반응한 어절 및 자음 오류의 갯수를 ‘조음오류 횟수’에 기록한다.

4. 언어적 오류(예를 들어 다른 말로 대치하거나 생략)가 있는 경우 1 회에 한해 다시 들려주고 따라 하도록 한다. 단 호랑이, 코끼리, 사슴/ 왕잔님 공준님의 발화 순서는 바꾸되 발음이 정확한 경우 정반응으로 한다.

5. 문법형태소를 축약하거나 생략하는 네 가지 경우(예: 자동찰/자동차를, 우린/우리는, 공준님/공준니미, 신/신이)와 문장마다 종결어미 '요'를 생략한 경우는 모두 정 반응으로 간주한다.

\section{* 따라하기 검사도구 화면 및 검사문항}

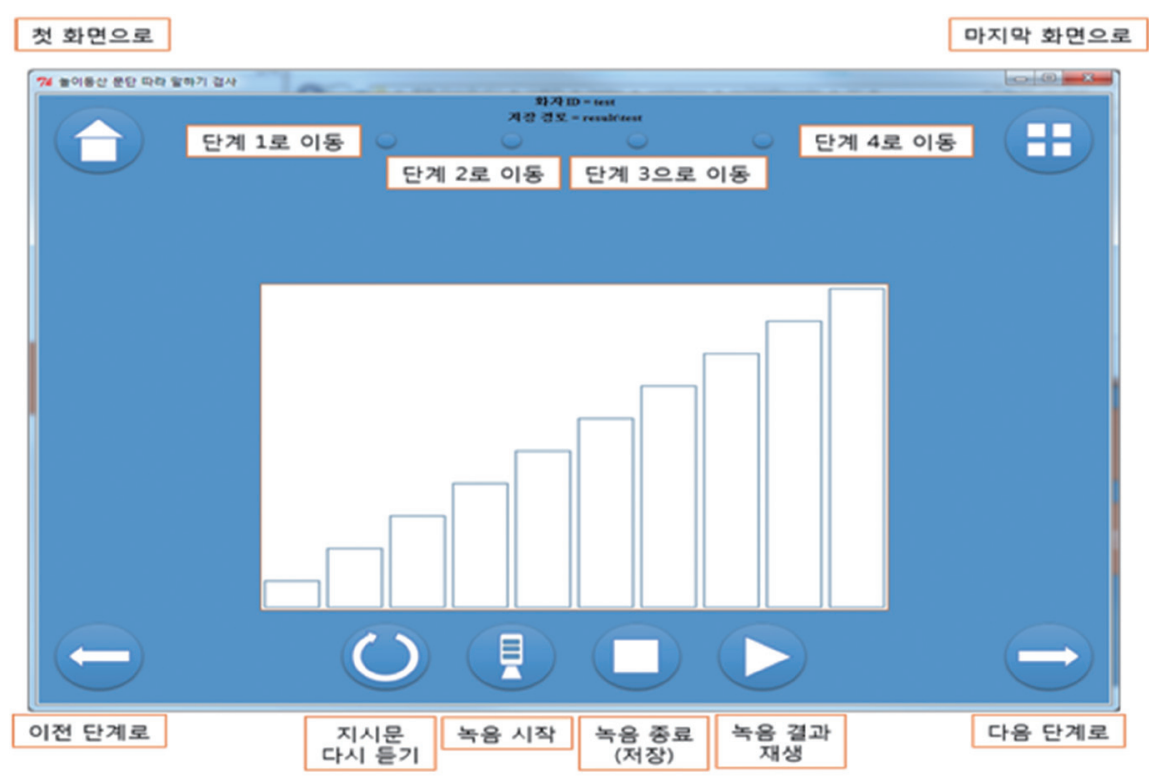




\section{국문초록}

\section{말소리장애 선별검사 개발 및 6세 아동의 출현율 조사}

\section{김수진}

나사렛대학교 언어치료학과

배경 및 목적: 본 연구는 6세 아동의 말소리장애 출현율을 알아보는 '세 문장 따라말하기 선별검사'를 개발하고 600 명의 아동에게 실 시하여 조음 오류점수와 평정점수를 산출하였다. 방법: 우선 선별검사의 선별정확도를 검증하고 말소리장애 출현율을 구하였다. 결과: 중등도 이상의 말소리장애가 있는 아동은 $2.3 \%$, 경계선에서 경도 아동은 $5.8 \%$ 로 나타났다. 논의 및 결론: 논의에서 성별, 지역, 동반장 애 등 다양한 특성에 따른 말소리장애 출현율 연구의 필요성을 제안하였다.

핵심어: 학령전기 아동, 말소리장애, 선별검사, 출현율

본 연구는 나사렛대학교에서 연구비를 지원받아 수행되었음.

\section{참고문헌}

고유경, 김수진(2016). 말소리장애 아동의 언어문제. 한국음성학회 춘계학술대회 발표논문집, 149-150.

김수진(2016). 5-6세 아동의 말소리장애 선별검사 개발. 한국언어청각임상학회 학술대회 발표논문집, 212-213.

김수진, 김민정, 하승희, 하지완(2015). 임상현장의 말소리장애 현황. 언어청각장애연구, 20, 133-144.

김수진, 김정미, 윤미선, 장문수, 차재은(2012). 자발화에 나타난 형태소 유형에 따른 3-4세 아동의 치경마찰음 오류. 말소리와음성과학, 4, 129-136.

김수진, 신지영(2015). 말소리장애. 서울: 시그마프레스.

김수진, 유하진(2014). 5세, 6세 아동을 위한 따라말하기 선별검사의 개발. 한국언어청각임상학회 학술대회 발표논문집, 43-46.

김수진, 한유진(2015). 따라말하기 선별검사의 타당도 및 언어장애 선별정확도: 컴퓨터를 활용한 5-6세용 놀이동산 문단. 언어치료연구, 24, 391-400.

박가연, 김수진(2015). 말소리장애 아동의 단어와 자발화 문맥의 음운오류패턴 비교. 말소리와 음성과학, 7, 165-173.

오경아, 김수진(2016). 연령과 검사 방법에 따른 따라말하기 검사 수행력 비교: 5,6세 아동을 위한 컴퓨터와 인쇄물 기반 검사. 한국음성학회 춘계학 술대회 발표논문집, 143-144.

우혜경, 김수진(2013). 자발화에 나타난 3-4세 아동의 어중종성 습득. 말소리와 음성과학, 5, 73-81.

최민실, 김수진(2013). 자발화에 나타난 3-4세 아동의 형태소 유형별 유음 발달 특성. 언어청각장애연구, 18, 76-85. 